incubation for $1 \mathrm{~h}$ at room temperature. After washing with PBS containing $0.2 \mathrm{mg} \mathrm{ml}^{-1} \mathrm{BSA}$, specific counts were measured. The IGOR program was used to determine $K_{\mathrm{d}}$. Cell-based equilibrium binding analysis ${ }^{9}$ was used to confirm the specificity of GDNFR- $\alpha$ and NTNR- $\alpha$ for GDNF and NTN, respectively. Each binding experiment was repeated at least 4 times. For PIPLC analysis, 293 cells transiently transfected with either the full-length NTNR- $\alpha$ expression construct or an irrelevant plasmid were incubated with $\sim 20,000$ c.p.m. ${ }^{125} \mathrm{I}-$ hNTN in the presence of the indicated amounts of PIPLC for $90 \mathrm{~min}$ at room temperature. The cells were washed with ice-cold PBS containing $0.2 \mathrm{mg} \mathrm{ml}^{-1}$ BSA, and cell-associated ${ }^{125}$ I was measured.

Survival assays. E14 rat motor neurons were purified, plated and grown in duplicate wells in L15 medium with the N2 supplement and $2 \%$ horse serum ${ }^{28}$. After 3 days in culture, only $30-40 \%$ of the motor neurons initially present survived in basal medium, whereas at saturating concentrations of GDNF or BDNF nearly all motor neurons remained alive. The increase in the number of surviving neurons in the presence of saturating concentrations of GDNF compared to basal medium was taken as $100 \%$ (maximal) survival; percentage of maximal survival under the indicated conditions is shown in Fig. 3b. PIPLC $\left(2 \mu \mathrm{g} \mathrm{ml}^{-1}\right)$ was added to the indicated samples $2 \mathrm{~h}$ before, as well as $12 \mathrm{~h}$ and $24 \mathrm{~h}$ after, addition of the indicated growth factors.

Tyrosine phosphorylation. To assay for tyrosine phosphorylation, cells were incubated for $1 \mathrm{~h}$ at $37^{\circ} \mathrm{C}$ with or without PIPLC and then exposed to NTN with or without soluble NTNR- $\alpha\left(10 \mu \mathrm{g} \mathrm{ml}^{-1}\right)$ for $5-10 \mathrm{~min}$ at $37^{\circ} \mathrm{C}$. Cells were then removed from the plates with 2 mM EDTA in PBS and lysed with icecold buffer (comprising, in mM 10 sodium phosphate ( $\mathrm{pH} 7.0$ ), $100 \mathrm{NaCl}, 1 \%$ NP40, $5 \mathrm{EDTA}, 100$ sodium vanadate, $2 \mathrm{mM}$ PMSF, and 0.2 units of aprotinin) and used for immunoprecipitation with antiserum raised against the 19 aminoacid C terminus of Ret, following by binding to protein A-Sepharose. The immunoprecipitated proteins were released by boiling in SDS sample buffer, separated on an $8 \%$ SDS-polyacrylamide gel, transferred to a nitrocellulose membrane, and reacted with anti-phosphotyrosine antibody (Upstate Biotechnology). Detection was with an ECL western blotting detection system (Amersham Life Science).

Co-immunoprecipitation. To examine the formation of protein complexes, TGW-I-nu cell were exposed to $500 \mathrm{ng} \mathrm{ml}^{-1}$ of NTN. Protein complexes were immunoprecipitated with Ret antibodies, transferred onto a nitrocellulose filter, and analysed with polyclonal antibody against NTN. Alternatively, HEK 293 cells were transiently transfected with expression vectors for Ret, an epitope-tagged NTNR- $\alpha$, or a combination of an epitope-tagged NTNR- $\alpha$ and Ret. Cells were stimulated with NTN as indicated and lysed with brij 96 detergent (Fluka) ${ }^{16}$. Putative immune complexes were immunoprecipitated with a polyclonal antibody against Ret, transferred onto a nitrocellulose filter, and analysed with a monoclonal antibody against the epitope-tagged NTNR- $\alpha$.

Received 7 March; accepted 1 May 1997

1. Lin, L. H., Doherty, D. H., Lile, J. D., Bektesh, S. \& Collins, F. GDNF: A glial cell line-derived neurotrophic factor for midbrain dopaminergic neurons. Science 260, 1130-1132 (1993).

2. Kotzbauer, P. T. et al. Neurturin, a relative of glial-cell-line-derived neurotrophic factor. Nature 384, $467-470$ (1996).

3. Henderson, C. E. et al. GDNF: A potent survival factor for motoneurons present in peripheral nerve and muscle. Science 266, 1062-1064 (1994).

4. Buj-Bell, A., Buchman, V. L., Horton, A., Rosenthal, A. \& Davies, A. M. GDNF is an age-specific survival factor for sensory and autonomic neurons. Neuron 15, 821-828 (1995).

Arenas, E., Trupp, M., Akerud, P. \& Ibáñez, C. F. GDNF prevents degeneration and promotes the phenotype of brain noradrenergic neurons in vivo. Neuron 15, 1465-1473 (1995).

6. Trupp, M. et al. Peripheral expression and biological activities of GDNF, a new neurotrophic factor for avian and mammalian peripheral neurons. J. Cell Biol. 130, 137-148 (1995).

Takahashi, M., Ritz, J. \& Cooper, G. M. Activation of a novel human transforming gene, ret, by DNA rearrangement. Cell 42, 581-588 (1985).

8. Takahashi, M. \& Cooper, G. M. ret Transforming gene encodes a fusion protein homologous to tyrosine kinases. Mol. Cell. Biol. 7, 1378-1385 (1987).

9. Treanor, J. J. S. et al. Characterization of a multicomponent receptor for GDNF. Nature 382, 80-83 (1996).

10. Jing, S. et al. GDNF-induced activation of the ret protein tyrosine kinase is mediated by GDNFR- $\alpha$, a novel receptor for GDNF. Cell 85, 1113-1124 (1996).

11. Trupp, M. et al. Functional receptor for GDNF encoded by the c-ret proto-oncogene. Nature 381, 785-789 (1996).

12. Durbec, P. et al. GDNF signalling through the Ret receptor tyrosine kinase. Nature 381, 789-793 (1996).

13. Koke, J. A., Yang, M., Henner, D. J., Volwerk, J. J. \& Griffith, O. H. High-level expression in Escherichia coli and rapid purification of phosphatidylinositol-specific phospholipase $\mathrm{C}$ from Bacillus cereus and Bacillus thuringiensis. Protein Expr. Purif. 2, 51-58 (1991).

14. Ikeda, I. et al. Specific expression of the ret proto-oncogene in human neuroblastoma cell lines. Oncogene 5, 1291-1296 (1990)

15. Takahashi, M., Buma, Y. \& Taniguchi, M. Identification of the ret proto-oncogene products in neuroblastoma and leukemia cells. Oncogene 6, 297-301 (1991).

16. Davis, S. et al. Released form of CNTF receptor $\alpha$ component as a soluble mediator of CNTF responses. Science 259, 1736-1739 (1993).
17. Schuchardt, A., D'Agati, V., Larsson-Blomberg, L., Costantini, F. \& Pachnis, V. Defects in the kidney and enteric nervous system of mice lacking the tyrosine kinase receptor Ret. Nature 367, 380-383 (1996).

18. Durbec, P. L., Larsson-Blomberg, L. B., Schuchardt, A., Costantini, F. \& Pachnis, V. Development 122, 349-358 (1996).

19. Pichel, J. G. et al. Defects in enteric innervation and kidney development in mice lacking GDNF. Nature 382, 73-76 (1996).

20. Sánchez, M. P. et al. Renal agenesis and the absence of enteric neurons in mice lacking GDNF. Nature 382, 70-73 (1996).

21. Moore, M. W. et al. Renal and neuronal abnormalities in mice lacking GDNF. Nature 382, 76-79 (1996)

22. Lindsay, R. M. \& Yancopoulos, G. D. GDNF in a bind with known orphan: Accessory implicated in new twist. Neuron 17, 571-574 (1996).

23. Ip, N. Y. et al. CNTF and LIF act on neuronal cells via shared signaling pathways that involve the IL-6 signal transducing receptor component gp130. Cell 69, 1121-1132 (1992).

24. Wrana, J. L., Attisano, L., Wieser, R., Ventura, F. \& Massague, J. Mechanism of activation of the TGF- $\beta$ receptor. Nature 370, 341-347 (1994)

25. Lee, J-D. et al. Glycosyl-phosphatidylinositol-anchored or integral membrane forms of CD14 mediate identical cellular responses to endotoxin. Proc. Natl Acad. Sci. USA 90, 9930-9934 (1993).

26. Pugin, J. et al. Lipopolysaccharide (LPS) activation of human endothelial and epithelial cells is mediated by LPS binding protein and soluble CD14. Proc. Natl Acad. Sci. USA 90, 2744-2748 (1993).

27. Hochuli, E., Dobeli, H. \& Schacher, A. New metal chelate adsorbent selective for proteins and peptides containing neighboring histidine residues. J. Chromatogr. 411, 177-184 (1987).

28. Henderson, C. E. et al. in Nerve Cell Culture: A Practical Approach (eds Cohen, J. \& Wilkin, G.) 69-81 (Oxford Univ. Press, 1995)

Acknowledgements. We thank J. Milbrandt and E. Johnson (who were supported by NIH grants) for providing unpublished information and reagents; W. Anstine for preparing the figures; E. Berry for help with the manuscript; A. Ryan for help with the in situ hybridization analysis; M. Vasser, P. Jhurani and P. Ng for synthetic oligonucleotides; M. Yang for the PIPLC enzyme; and V. Arce for help with motor neuron cultures. This work was supported in part by INSERM, Association Francaise contre les Myopathies (AFM) and Institut pour la Recherche sur la Moelle Epiniere (IRME) to C.E.H., and by grants-in-aid from scientific research from the Ministry of Education, Science and Culture of Japan to M.T.

Correspondence and requests for materials should be addressed to A.R. (e-mail: ar@gene.com).

\section{Neurturin responsiveness requires a GPI-linked receptor and the Ret receptor tyrosine kinase}

\section{Anna Buj-Bello*`, Jimi Adu`, Luzia G. P. Piñón*, Antony Horton*, Jane Thompson*, Arnon Rosenthal $†$, Miguel Chinchetru $\ddagger$ Vladimir L. Buchman* \& Alun M. Davies*}

* School of Biological and Medical Sciences, Bute Medical Buildings, University of St Andrews, St Andrews, Fife KY16 9AT, UK

$\dagger$ Department of Neuroscience, Genentech, Inc., 460 Point San Bruno Boulevard, South San Francisco, California 94080, USA

$\ddagger$ Present address: Departmento de Bioquimica y Biologia Molecular,

Facultad de Veterinaria, Universidad de León, 24007 León, Spain

$\$$ These authors contributed equally to this work.

Neurturin $(\mathrm{NTN})^{1}$ is a recently identified homologue of glial-cellline-derived neurotrophic factor $(\mathrm{GDNF})^{2}$. Both factors promote the survival of a variety of neurons ${ }^{1-5}$, and GDNF is required for the development of the enteric nervous system and kidney ${ }^{6-8}$. GDNF signals through a receptor complex consisting of the receptor tyrosine kinase Ret and a glycosyl-phosphatidylinositol (GPI)-linked receptor termed GDNFR- $\alpha^{9-13}$. Here we report the cloning of a new GPI-linked receptor termed NTNR- $\alpha$ that is homologous with GDNFR- $\alpha$ and is widely expressed in the nervous system and other tissues. By using microinjection to introduce expression plasmids into neurons, we show that coexpression of NTNR- $\alpha$ with Ret confers a survival response to neurturin but not GDNF, and that coexpression of GDNFR- $\alpha$ with Ret confers a survival response to GDNF but not neurturin. Our findings indicate that GDNF and neurturin promote neuronal survival by signalling through similar multicomponent receptors that consist of a common receptor tyrosine kinase and a member of a GPI-linked family of receptors that determines ligand specificity. 


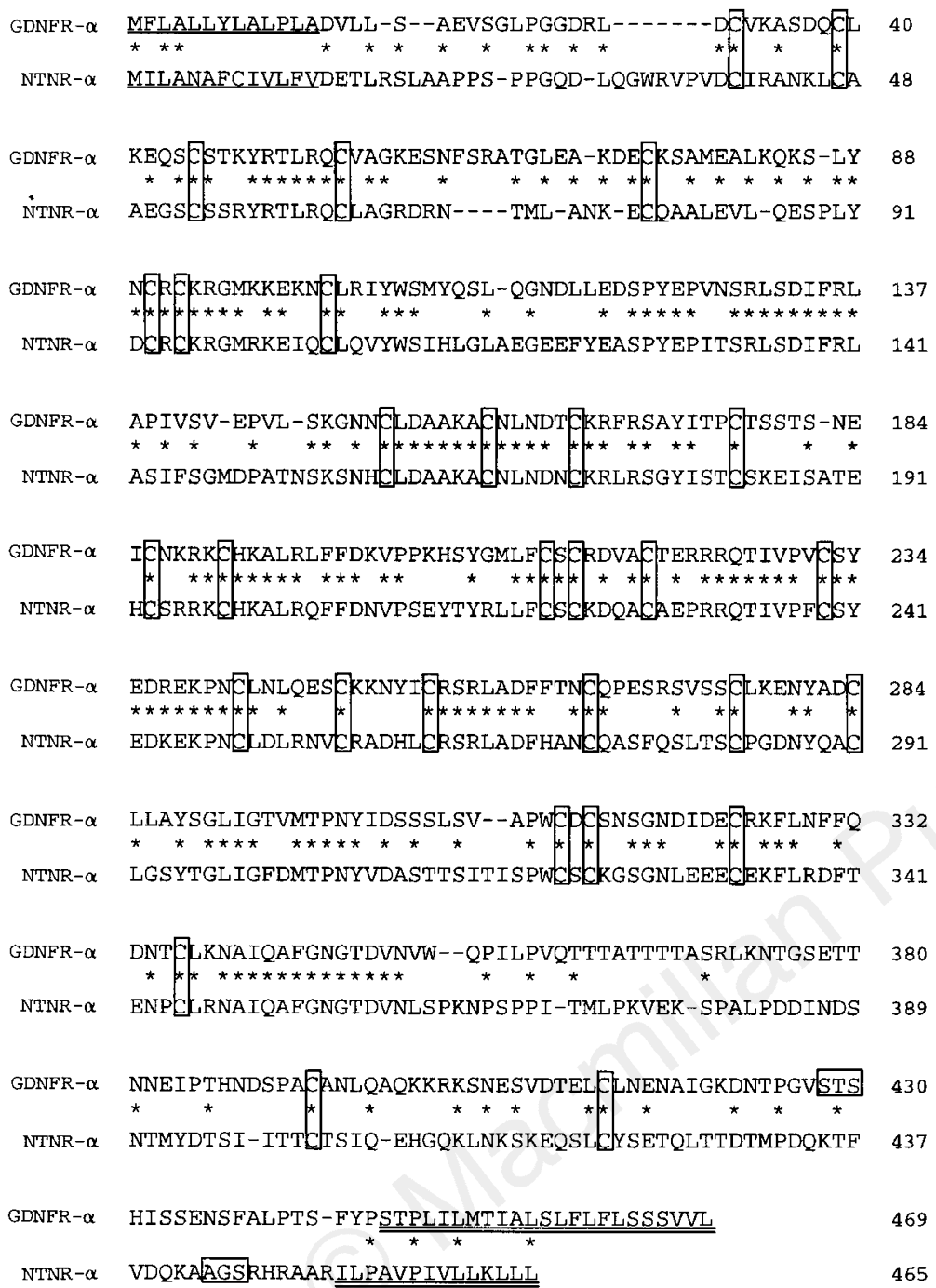

We have screened an embryonic-day-10 (E10) chicken brain cDNA library at low stringency using the full coding region of mouse GDNFR- $\alpha$ as a probe, and isolated two sets of overlapping cDNAs clones encoding chicken GDNFR- $\alpha$ and a GDNFR- $\alpha$ homologue designated, for reasons given below, neurturin receptor $\alpha($ NTNR- $\alpha)$ (Fig. 1). The predicted chicken GDNFR- $\alpha$ is a protein of 469 amino acids which has $80 \%$ identity with rodent GDNFR- $\alpha$. NTNR- $\alpha$ is a protein of 465 amino acids that has $49 \%$ identity with chicken GDNFR- $\alpha$, including conservation of all 30 cysteines. Both GDNFR- $\alpha$ and NTNR- $\alpha$ possess an amino-terminal, hydrophobic, putative signal peptide for secretion, and the characteristic carboxyterminal feature of GPI-linked proteins: a C-terminal hydrophobic domain separated by a hydrophilic linker region from a cleavage/ binding consensus sequence for GPI linkage (Ser-Thr-Ser for GDNFR- $\alpha$, and Ala-Gly-Ser for NTNR- $\alpha)^{14}$. These features suggest that both GDNFR- $\alpha$ and NTNR- $\alpha$ are secreted proteins attached to the extracellular surface of the plasma membrane.

To ascertain the potential involvement of NTNR- $\alpha$ in the survival responses of developing neurons to neurotrophic factors and to compare its function with that of GDNFR- $\alpha$, we used microinjection to introduce expression plasmids encoding NTNR- $\alpha$ and GDNFR- $\alpha$ into cultured neurons that do not survive with either GDNF or neurturin. From a survey of several different populations of neurons, we found that sympathetic neurons of the superior cervical sympathetic ganglion (SCG) of postnatal day 4 (P4) mice are not supported by either neurturin or GDNF in culture. Reverse
Figure 1 Aligned sequences of chicken GDNFR- $\alpha$ and NTNR- $\alpha$. Identical amino acids are marked with asterisks and the conserved cysteines are enclosed in vertical boxes. The $\mathrm{N}$-terminal, hydrophobic, putative signal peptides are underlined; the Cterminal hydrophobic domain is double-underlined; and the putative binding/cleavage consensus sequences for GPI linkage are enclosed in horizontal boxes. GenBank accession numbers: GDNFR- $\alpha$, U90541; NTNR- $\alpha$, U90542. 

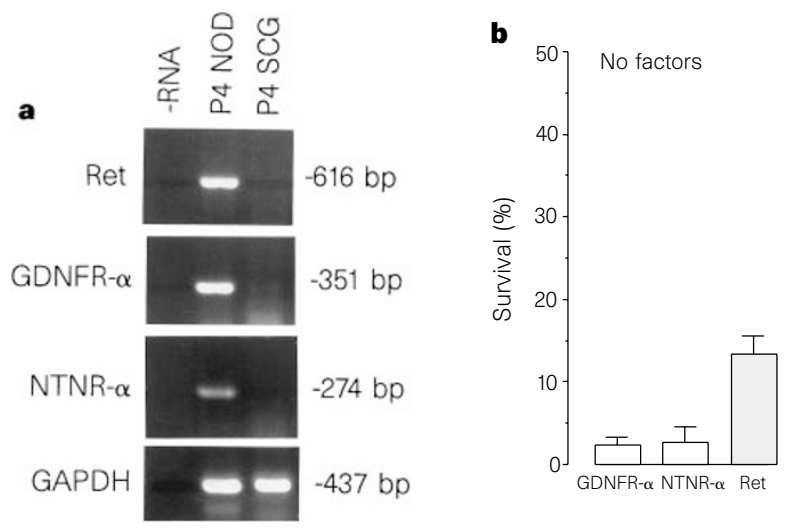

Figure 2 a, RT-PCR detection of endogenous $c$-Ret, GDNFR- $\alpha$ and NTNR- $\alpha$ transcripts in mouse P4 SCG neurons (which do not respond to GDNF and neurturin) and P4 mouse nodose neurons (which do respond to these factors). The presence of similar amount of the total RNA in samples is demonstrated by amplification of the 437-bp fragment of GAPDH mRNA. b, Survival of P4 mouse
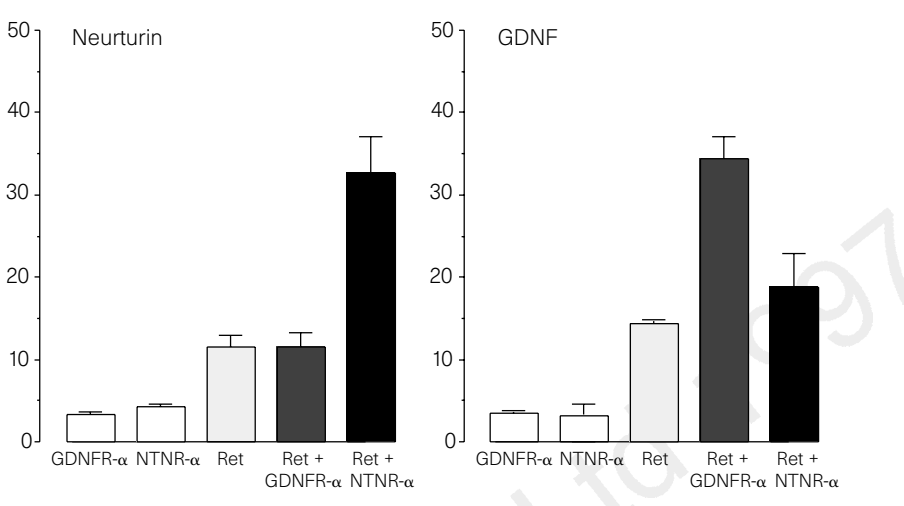

SCG neurons $48 \mathrm{~h}$ after injection with expression plasmids for GDNFR- $\alpha$ and NTNR- $\alpha$ and Ret, singularly and in combination. The injected neurons were incubated in medium containing either neurturin or GDNF. Results are means ( + s.e.) of the combined results of 8 separate experiments $(n \geq 4$ for each experiment condition).

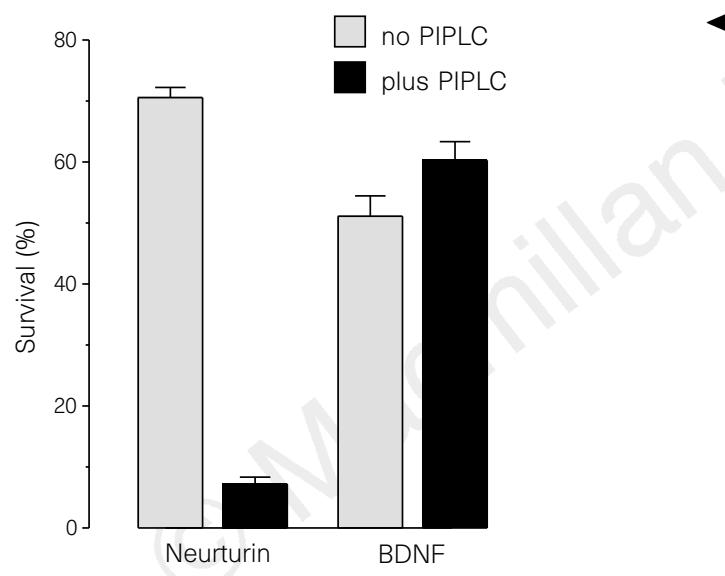

to GDNF and neurturin. However, neurons coexpressing NTNR- $\alpha$ plus Ret had a substantially enhanced survival response to neurturin which was significantly greater than that of neurons expressing Ret alone $(P=0.003, t$-test, $n=6)$. Similarly, neurons coexpressing GDNFR- $\alpha$ plus Ret had a substantially enhanced survival response to GDNF which was significantly greater than that of neurons expressing Ret alone $(P=0.0002$, $t$-test, $n=8)$. In contrast, neurons coexpressing GDNFR- $\alpha$ plus Ret showed no enhanced survival response to neurturin; there were no more neurons expressing Ret/GDNFR- $\alpha$ surviving with neurturin than neurons expressing Ret. Similarly, the number of neurons expressing Ret/ NTNR- $\alpha$ surviving with GDNF was not significantly different from the number of neurons expressing Ret surviving with this factor $(P>0.2, t$-test, $n=8)$. These results imply that GDNFR- $\alpha$ and NTNR- $\alpha$ are receptors for GDNF and neurturin, respectively, and that Ret is required for signalling and the survival response of neurons to both factors. Although GDNFR- $\alpha$ and NTNR- $\alpha$ in the presence of Ret conferred specific survival responses to GDNF and neurturin at concentrations up to $5 \mathrm{ng} \mathrm{ml}^{-1}$, at 10 -fold higher concentrations of these factors some cross-talk in responsiveness was observed (see Supplementary Information).

To investigate further whether a GPI-linked protein is normally required for the survival response of neurons to neurturin, we treated neurturin-responsive embryonic chicken nodose ganglion neurons with phosphoinositide-specific phospholipase C (PIPLC), an enzyme that specifically cleaves GPI linkages ${ }^{16}$. PIPLC treatment reduced the number of neurons surviving with neurturin from over $70 \%$ to less than $10 \%$ (Fig. 3). This was not due to a neurotoxic effect of PIPLC, because the survival response of nodose neurons to brain-derived neurotrophic factor (BDNF), which signals through the transmembrane TrkB receptor tyrosine kinase ${ }^{17}$, was unaffected by PIPLC treatment (Fig. 3). Similarly, the neurturin survival response of P4 SCG neurons coexpressing Ret and NTNR- $\alpha$ was significantly reduced from $30.6 \pm 2.9 \%$ to $9.2 \pm 3.0 \%$ by PIPLC treatment $(P<0.01, t$-test, $n=4)$. The survival of these PIPLCtreated neurons was not significantly different from the survival of neurons expressing Ret alone $(13.3 \pm 2.2 \%, P>0.05)$. This indicates that PIPLC treatment had eliminated the specific neurturin survival response in these neurons, which in turn demonstrates that ectopically expressed NTNR- $\alpha$ is required for this response.

Northern blotting was used to study the expression of GDNFR- $\alpha$ and NTNR- $\alpha$ transcripts in chicken embryos at different developmental stages (Fig. 4). A 10-kilobase (kb) GDNFR- $\alpha$ transcript and $3.4-\mathrm{kb}$ and $2.8-\mathrm{kb} N T N R-\alpha$ transcripts were expressed in the nervous system and several other tissues. Regional and developmental differences in the levels of these transcripts were apparent in these tissues.

In summary, we have identified a specific GPI-linked receptor for neurturin that is structurally related to GDNFR- $\alpha$. We have shown that the survival responses of neurons to neurturin and GDNF require NTNR- $\alpha$ and GDNFR- $\alpha$, respectively, together with a common transmembrane receptor tyrosine kinase, Ret. Our 


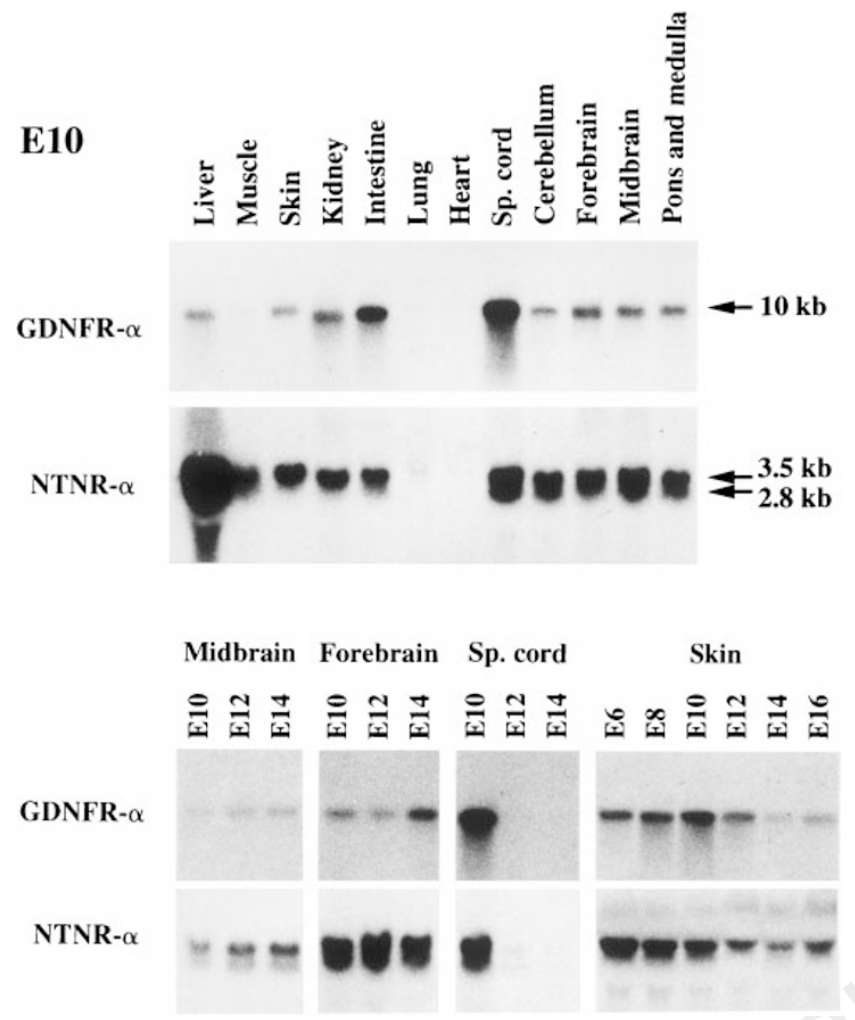

Figure 4 Analysis of the expression of GDNFR- $\alpha$ and NTNR- $\alpha$ mRNAs by northern blotting. Similar amounts of total RNA from various embryonic tissues at E10 (top) and skin and regions of the central nervous system (bottom) were transferred to filters and hybridized sequentially with GDNFR- $\alpha$ and NTNR- $\alpha$ probes. Bands corresponding to the 10-kb GDNFR- $\alpha$ and 3.5-kb and 2.8-kb NTNR- $\alpha$ transcripts are indicated. Sp. Cord, spinal cord.

demonstration that NTNR- $\alpha$ and GDNFR- $\alpha$ are required for ligand discrimination in the physiological responses of neurons to neurturin and GDNF is consistent with the results of binding studies which show that NTNR- $\alpha$ and GDNFR- $\alpha$ are specific high-affinity receptors for neurturin and GDNF, respectively ${ }^{18}$. Furthermore, because we investigated the actions of mammalian neurturin and GDNF on avian receptors, our study also shows that the specific, functional interactions between these neurotrophic factors and their corresponding GPI-linked receptors have been conserved between two classes of vertebrates. Previous studies have identified several unrelated GPI-linked, ligand-binding components of multicomponent receptors, such as the CNTF receptor ${ }^{15}$ and the bacterial endotoxin receptor ${ }^{19,20}$. However, we have established the existence of a family of GPI-linked proteins that discriminate between structurally related ligands in multicomponent receptors that share a common transmembrane signalling component.

\section{Methods}

Receptor cloning and expression. An E10 chicken brain cDNA library in $\lambda$ ZAPII was screened ${ }^{21}$ using a mouse GDNF cDNA probe at low stringency (hybridization at $59^{\circ} \mathrm{C}$, final wash at $65^{\circ} \mathrm{C}$ in $2 \mathrm{X}$ SSC, $0.2 \%$ SDS). Five GDNFR$\alpha$ and three NTNR- $\alpha$ cDNA independent clones were sequenced. Northern blot analysis ${ }^{21}$ used unique regions of the GDNFR- $\alpha$ and NTNR- $\alpha$ cDNAs as specific probes. For RT-PCR analysis of GDNFR- $\alpha, N T N R-\alpha$ and $c$-Ret mRNA expression in cultured mouse neurons, total RNA was reverse transcribed and amplified ${ }^{22}$. The amounts of total RNA in samples were normalized by amplification of a 437-bp fragment of glyceraldehyde-3-phosphate dehydrogenase mRNA ${ }^{22}$. The primers were as follows: c-Ret, $5^{\prime}$-TGTATGTAGACCAGCCAGCT-3' and 5'-ACTATGCACAAAGCCTCCAG-3'; GDNFR- $\alpha$, 5-
CATGTTCCTAGCCACTCTGT-3' and $5^{\prime}$-TCCAGTAGGTCATTTCCCTG-3'; NTNR- $\alpha, 5^{\prime}$-ATGATCTTGGCAAACGCCCTTCTG-3' and $5^{\prime}$-GCTTCATAGAACTCCTCACCCTC- $3^{\prime}$. Amplification was carried out for 40 cycles of $95^{\circ} \mathrm{C}$ for $45 \mathrm{~s} ; 54^{\circ} \mathrm{C}$ for $30 \mathrm{~s}$; and $72^{\circ} \mathrm{C}$ for $60 \mathrm{~s}$.

Neuronal culture and microinjection studies. Purified P4 SCG neurons were grown in defined medium ${ }^{23}$. After incubation for $12 \mathrm{~h}$ with $\mathrm{NGF}\left(2 \mathrm{ng} \mathrm{ml}^{-1}\right)$, the neurons were washed extensively to remove NGF and injected with expression plasmids into the nucleus (GDNFR- $\alpha$ cDNA and NTNR- $\alpha$ cDNA in pMEX, and $c$-Ret cDNA in $\mathrm{pRC/CMV)}$ as described ${ }^{24}$. The cultures were supplemented with either GDNF or neurturin immediately after injection, and the number of surviving neurons was counted $48 \mathrm{~h}$ later and is expressed as a percentage of the number injected. To investigate the importance of GPI-linked proteins in neurturin responsiveness, neurturin-responsive E6 chicken nodose neurons were cultured in $11-\mathrm{mm}$ diameter wells ${ }^{25}$. BDNF $\left(5 \mathrm{ng} \mathrm{ml}^{-1}\right)$ or neurturin $\left(5 \mathrm{ng} \mathrm{ml}^{-1}\right)$ was added to the cultures $1.5 \mathrm{~h}$ after plating, and half of the cultures were supplemented with PIPLC $\left(4 \mu \mathrm{g} \mathrm{ml}^{-1}\right)$ at the time of plating and after a further 12 and $24 \mathrm{~h}$ (ref. 9). The number of surviving neurons was counted at $36 \mathrm{~h}$, and is expressed as a percentage of the number plated.

Received 7 March; accepted 19 May 1997.

1. Kotzbauer, P. T. et al. Neurturin, a relative of glial-cell-line-derived neurotrophic factor. Nature 384, 467-470 (1996).

2. Lin, L. H., Doherty, D. H., Lile, J. D., Bektesh, S. \& Collins, F. GDNF: A glial cell-derived neurotrophic factor for midbrain dopaminergic neurons. Science 260, 1130-1132 (1993).

3. Henderson, C. E. et al. GDNF: A potent survival factor for motoneurons present in peripheral nerve and muscle. Science 266, 1062-1064 (1994).

4. Buj-Bello, A., Buchman, V. L., Horton, A., Rosenthal, A. \& Davies, A. M. GDNF is an age-specific survival factor for sensory and autonomic neurons. Neuron 15, 821-828 (1995).

5. Trupp, M. et al. Peripheral expression and biological activities of GDNF, a new neurotrophic factor for avian and mammalian peripheral neurons. J. Cell Biol. 130, 137-148 (1995).

6. Moore, M. W. et al. Renal and neuronal abnormalities in mice lacking GDNF. Nature 382, 76-79 (1996).

7. Pichel, J. G. et al. Defects in enteric innervation and kidney development in mice lacking GDNF. Nature 382, 73-76 (1996).

8. Sanchez, M. P. et al. Renal agenesis and the absence of enteric neurons in mice lacking GDNF. Nature 382, 70-73 (1996).

9. Treanor, J. et al. Characterization of a receptor for glial cell line-derived neurotropic factor. Nature 382, 80-83 (1996).

10. Jing, S. et al. GDNF-induced activation of the ret protein tyrosine kinase is mediated by GDNFR- $\alpha$, a novel receptor for GDNR. Cell 85, 1113-1124 (1996).

11. Trupp, M. et al. Functional receptor for GDNF encoded by the c-ret proto-oncogene. Nature 381, 785-789 (1996).

12. Durbec, P. et al. GDNF signalling through the Ret receptor tyrosine kinase. Nature 381, 789-793 (1996).

13. Vega, Q. C., Worby, C. A., Lechner, M. S., Dixon, J. E. \& Dressler, G. R. Glial cell line-derived neurotrophic factor activates the receptor tyrosine kinase RET and promotes kidney morphogenesis. Proc. Natl Acad. Sci. USA 93, 10657-10661 (1996).

14. Gerber, L. D., Kodukula, K. \& Udenfried, S. Phosphatidylinositol glycan (PI-G) anchored membrane proteins. Amino acid requirements adjacent to the site of cleavage and PI-G attachment in the COOH-terminal signal peptide. J. Biol. Chem. 267, 12168-12173 (1992).

15. Davis, S. et al. LIFR $\beta$ and gp130 as heterodimerizing signal transducers of the tripartite CNTF receptor. Science 260, 1805-1808 (1993).

16. Koke, J. A., Yang, M., Henner, D. J., Volwerk, J. J. \& Griffin, O. H. High-level expression in Escherichia coli and rapid purification of phosphatidylinositol-specific phospholipase $\mathrm{C}$ from Bacillus cereus and Bacillus thuringiensis. Protein Expr. Purif. 2, 51-58 (1991).

17. Klein, R. et al. The trkB tyrosine protein kinase is a receptor for brain-derived neurotrophic factor and neurotrophin-3. Cell 66, 395-403 (1991).

18. Klein, R. D. et al. A GPI-linked protein that interacts with Ret to form a candidate neurturin receptor. Nature 387, 717-721 (1997).

19. Lee, J. D. et al. Glycosyl-phosphatidylinositol-anchored or integral membrane forms of CD14 mediate identical cellular responses to endotoxin. Proc. Natl Acad. Sci. YSA 90, 9930-9934 (1993).

20. Pugin, J. et al. Lipopolysaccharide activation of human endothelial and epithelial cells is mediated by lipopolysaccharide-binding protein and soluble CD14. Proc. Natl Acad. Sci. USA 90, 2744-2747 (1993).

21. Baka, I. D. et al. Intracellular compartmentalisation of two differently spliced S-REX/NSP mRNAs in neurons. Mol. Cell Neurosci. 7, 289-303 (1996).

22. Ninkina, N. et al. Expression and function of TrkB variants in developing sensory neurons. EMBO J. 15, 6385-6393 (1996).

23. Davies, A. M., Minichiello, L. \& Klein, R. Developmental changes in NT3 signalling via TrkA and TrkB in embryonic neurons. EMBO J. 14, 4482-4489 (1995).

24. Allsopp, T. E., Wyatt, S., Paterson, H. F. \& Davies, A. M. The proto-oncogene bcl-2 can selectively rescue neurotrophic factor-dependent neurons from apoptosis. Cell 73, 295-306 (1993).

25. Buj-Bello, A., Pinon, L. G. \& Davies, A. M. The survival of NGF-dependent but not BDNF-dependent cranial sensory neurons is promoted by several different neurotrophins early in their development. Development 120, 1573-1580 (1994)

Supplementary information is available on Nature's World-Wide Web site (http://www.nature.com) or as paper copy from Mary Sheehan at the London editorial office of Nature.

Acknowledgements. We thank H. Philips, R. Klein, R. Vandlen, B. Moffet and L. Simmons for the purified recombinant GDNF and neurturin; J. Winslow and G. Burdon for the purified recombinant BDNF; and D. Roche and J. Allan for preparing the illustrations. This work was supported by Action Research and the Wellcome Trust.

Correspondence and requests for materials should be addressed to A.M.D. (e-mail: amd2@st-and.ac.uk). 